\title{
REPORT ON THE CONCORDIA COLLOQUIUM ON LANGUAGE LABORATORIES
}

\author{
Roger Kenner.
}

July 6, 1981 saw one hundred and fifty language teachers and language laboratory directors, representing nine countries, gathered together at Concordia University in Montreal for a three day colloquium on language laboratories the theme of which was "A Renaissance for the Language Lab."

Why are the language labs in need of a "renaissance"? At the commercial exposition, in which many of the major manufacturers in the field of language laboratories showed their latest products, it was evident that research and development on the hardware has continued unceasingly. Cassettes have replaced reel-to-reel tapes. Teacher consoles and student controls are simpler and more reliable, thanks to printed-circuit technology. Microprocessors offer the instructor a range of new control and feedback options. Video playback capabilities are being integrated into the lab, as is computer-assisted-instruction. Portable language labs and low-cost wireless systems are making the hardware ever more accessible. In short, the "look" of the language laboratory of the 1980's in much different from that of the language lab discussed in 1970 at the First Canadian Conference on Language Laboratories, also held in Montreal.

Work on the development of new approaches to the use of the facility faltered during the 70's, however. Much of the material' put forward for use was of the same meaningless, mechanical variety as that produced during the heyday of the audio-lingual method. Instructors were abandoning the language lab. It was apparently no longer relevant in the age of the functional/notional approach and the communicative syllabus.

There were, nevertheless, a few lights in the wilderness. In scattered centres, independently, imaginative and innovative ways of using the resources of the language lab were being tried. It seemed to the organizers of the Concordia Colloquium that what was needed was a gathering together of these new ideas and a consensus on how the language laboratory might develop in the coming decade. The decision to hold a meeting in Montreal in 1981 was a step in that direction.

If any conclusions are to be drawn from the three-day meeting, the primary one must be that the language laboratory of the past is destined to become the open learning centre of the future. Modular instruction is definitely one direction of development, as is the preparation of software to take advantage of video playback capabilities and computer-assistedinstruction. Meaningful', communicative drills must replace merely mechanical manipulations of language. 
The onus, then, falls on the educators and on the publishers to produce and distribute software that will take full advantage of the possibilities offered by the new hardware and to provide guidance to equipment manufacturers on desirable lines of development for the future.

These themes were repeatedly stressed in the keynote addresses; "Language and Communication in the 1980's: The Role of the Language Laboratory", delivered by Dr. Gilbert Taggart of Concordia University, and "The State of the Art: Perspectives for the 1980's", given by Joseph Sheehan of the University of Houston and President of N.A.L.L.D.

Joan Morley of the University of Michigan drew a standing ovation with her plenary speech, "Active Participation/Purposeful Listening in the Language Laboratory: Aspects of Theory and Practice". In her presentation, she was able to translate the latest developments in second-language acquisition research into meaningful suggestions and applications for language laboratory use.

Three workshops treated the topic of modular instruction in the language lab. Jean Philippe Aubert and Marie-Noelle Legoux discussed the development of modular software for use in a traditional language laboratory and Carol Fraser analysed the factors involved in setting up an "Open Learning Centre".

Phyllis Vogel and Dana Paramskas, in separate workshops, dealt with the integration of the language laboratory into the language-teaching curriculum as a whole. Ms. Vogel's emphasis was on English as a second language while Ms. Paramskas drew her examples from the teaching of French as a second language.

The programme included a number of workshops on the development of materials for use in the language lab.

Dr. Gary Boyd discussed the design of visuals for use in the lab. Roger Godbout and Daniel Guay talked about the creation of material to respond to specific needs in the classroom. Joan Morley demonstrated various possibilities for materials designed to develop listening skills. Isabelle Sawyer focused on open-ended materials that give the student the opportunity to play an active role in the machine-student exchange. Gerald Strei showed participants how to prepare drills which were meaningful and communicative. Dr. Gilbert Taggart stressed the importance of using authentic documents in lab work and the use of visual cues to audio exercises.

Marlene Popper's workshop featured the use of the lab in a structured reading programme. Dr. Robert Vanderplank, in a late addition to the programme, spoke on the use of stress drills to aid the development of listening comprehension skills.

Computer-assisted-instruction was the subject of no less than five separate presentations. 
Glyn Holmes and Marilyn Kidd examined the principles of courseware design for C.A.I. Griff Richards outlined important considerations in setting up a C.A.I. system. Roger Kenner traced the development of the mainframe C.A.I. delivery system at Concordia University, and Donna Mydlarski discussed her experiences with a mini-computer system at the University of Calgary. Bernard Landriault and Guy Connolly illustrated the use of the PLATO system in teaching French.

Due attention was also given to the design and installation of facilities. Tom Rich gave a workshop on the procedures to be followed in selecting and purchasing the right language laboratory equipment for one's needs. Gary Kershaw talked about Concordia University's experience in constructing a language laboratory in-house. Michael Kay and A. Vyhnak gave an account of their similar experience at York University.

Liliana Baltra talked about the use of language laboratories for specific purposes in Chile.

Selected papers from the Colloquium are currently being collected for publication. The Proceedings should be available in book form by the Spring of 1982.

There was a general consensus at the end of the event that the momentum which had been developed should not be allowed to fall off. Gerald Strei of Nova University offered to begin preparing for a follow-up colloquium on language laboratories to be held in the Spring of 1984.

For more information concerning the Concordai Colloquium on Language Laboratories, Contact:

Roger Kenner
Director-Language Laboratories
Concordia University
1455 deMaisonneuve West
Montreal, Quebec, Canada
H3G-1M8

For your convenience in contacting speakers, their affiliations are listed below:

Name

Jean Philippe Aubert

Liliana Baltra

Gary Boyd

Carol Fraser

Roger Godbout \&

Daniel Guay

Glyn Holmes \&

Marilyn Kidd
Institution

McGill University

Ministry of Education

Concordia University

McGill University

Universite Laval

University of Western

Ontario
City

Montreal

Santiago, Chile

Montreal

Montreal

Ste. Foy, Quebec

London, Ontario 
Michael Kay \&

A. Vhynak

Gary Kershaw

Donna Mydlarski

Griff Richards

Bernard Landriault \&

Guy Connolly

Marie Noelle Legoux

Joan Morley

Dana Paramskas

Marlene Popper

Tom Rich

Isabelle Sawyer

Gerald Strei

Gilbert Taggart

Robert Vanderplank

Phyllis Vogel
York University

Concordia University

University of Calgary

Canadian Forces

Universite de Montreal

McGill University

University of Michigan

University of Guelph

Nova University

Ministry of Education

Simon Fraser University

Nova University

Concordia University

University of Edinburgh

Concordia University
Toronto, Ontario

Montreal

Calgary, Alberta

Trenton, Ontario

Montreal

Montreal

Ann Arbor, Michigan

Guelph, Ontario

Ft. Lauderdale, Wlorida

Prince Edward Island

Vancouver, B.C.

Ft. Lauderdale, Florida

Montreal

Edinburgh, Scotland

Montreal

The following companies took part in the exposition:

Panasonic (Canada) Ltd.

J. L. Electron Ltee.

Educational Media

Sony (Canada) Ltd.

Centre Educatif et Culture

Tandberg Ltd.

(Thorvin Electronics)

Mississauga, Ontario

Language Lab

Rimouski, Quebec

Language Lab

Oklahoma City, Oklahoma Language Lab

Willowdale, Ontario

Language Lab

Montreal

Books \& Tapes

Studer-Revox (Canada) Ltd.

Mississauga, Ontario

Language Lab

Toronto, Ontario

$\mathrm{P} / \mathrm{H}$ Electronics

Dayton, Ohio

Montreal

Language Lab

Cinedessins Enrg.

Montreal

Didacta

Longueuil, Quebec

Language Lab

Language Lab

Books \& Tapes

Language Lab 


\section{A LAB TO FIT YOUR BUDGET}

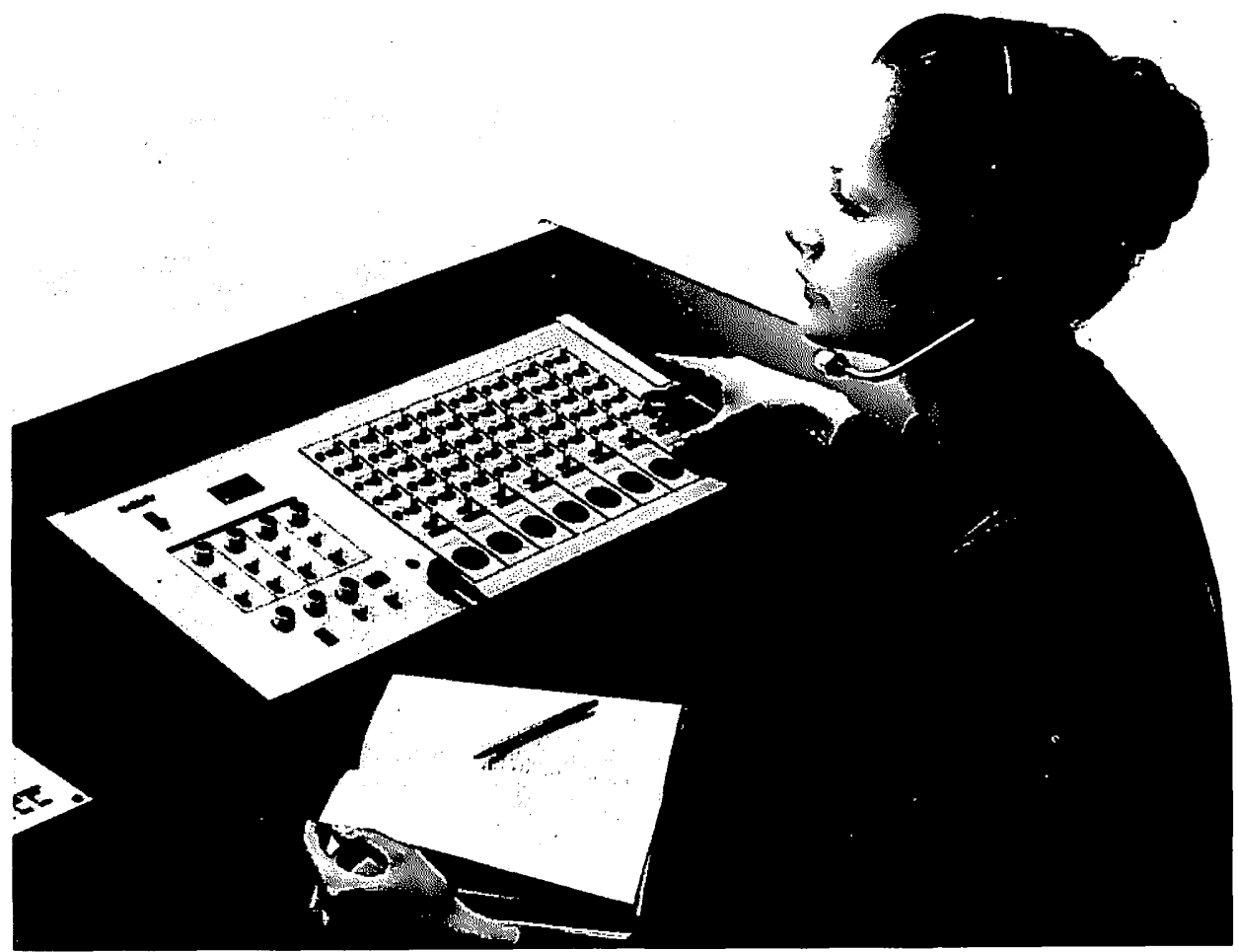

The latest addition to Sony Learning Systems' complete products is the LLC-8A, 40-position Instructor's Control Panel for use in low-cost labs.

This panel joins the other available models (LLC-1000, LLC-7 and LLC-11) to offer an added choice of control console when buying a lab on a limited budget.

Another product of Sony's total-system engineering, the LLC-8A offers their usual reliability and ease of operation. Can be used with a selection of recorders or booth amplifiers.

For more information call your Sony Learning Systems Dealer or

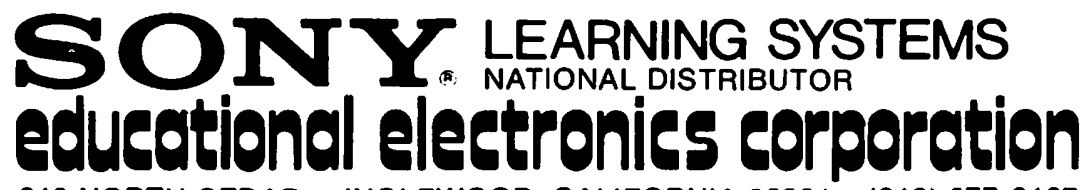

213 NORTH CEDAR • INGLEWOOD, CALIFORNIA $90301 \cdot(213)$ 677-8167 